\title{
The Effect of Npk+Mg Fertilizer Application on Potassium Availability, Potassium Uptake, and Yield of Sweet Corn (Zea mays Saccharata Sturt) in Inceptisols
}

\author{
Erika Oktaviani Ely ${ }^{*}$ Emma Trinurani Sofyan, Dirga Sapta Sara \\ Department of Soil Science, Faculty of Agriculture, Universitas Padjadjaran, Bandung, Indonesia \\ Email address: \\ erikaoktavianiely@gmail.com (E. O. Ely), emma.trinurani@unpad.ac.id (E. T. Sofyan),dirga.sapta@unpad.ac.id (D. S. Sara) \\ ${ }^{*}$ Corresponding author
}

\section{To cite this article:}

Erika Oktaviani Ely, Emma Trinurani Sofyan, Dirga Sapta Sara. The Effect of Npk+Mg Fertilizer Application on Potassium Availability, Potassium Uptake, and Yield of Sweet Corn (Zea mays Saccharata Sturt) in Inceptisols. International Journal of Energy and Environmental Science. Vol. 5, No. 3, 2020, pp. 47-50. doi: 10.11648/j.ijees.20200503.11

Received: January 7, 2020; Accepted: January 18, 2020; Published: August 27, 2020

\begin{abstract}
Essential nutrient needs for the growth of sweet corn can be fulfilled by the fertilization process. The combination of NPK $+\mathrm{Mg}$ fertilizer is one of the options to obtain adequate nutrient availability and increase sweet corn yield. This research aimed to determine the effect of NPK $+\mathrm{Mg}$ fertilizer on potassium availability, potassium uptake, and yield of sweet corn (Zea mays saccharata Sturt) Talenta variety in Inceptisols Jatinangor. This experiment was conducted at research field of Soil Fertility and Plant Nutrition, Department of Soil Science and Land Resources, Faculty of Agriculture, Universitas Padjadjaran from May to August 2019. The experimental design that had been used in this research was Randomized Block Design (RDB), which consisted 6 treatments of 1 control treatment, 1 standard NPK fertilizer treatment, and 4 treatments of NPK 12:12:17+9 $\mathrm{MgO}$ in different dosage. Each treatment was repeated four times so that there were 24 experimental plots. The results showed that the combination of NPK $+\mathrm{Mg}$ fertilization gave significant effect to the potassium availability, potassium uptake, and yield of sweet corn. 1 dosage of NPK $+\mathrm{Mg}$ fertilization $\left(250 \mathrm{~kg} \mathrm{ha}^{-1}\right)$ gave the best effect on increasing potassium availability of 2,25 $\mathrm{cmol} \mathrm{kg}^{-1}$, potassium uptake of 1,50\%, and the yield of sweet corn of 8,68 ton hectare ${ }^{-1}$ in Inceptisols Jatinangor.
\end{abstract}

Keywords: Inceptisols, NPK+Mg Fertilizer, Potassium Availability, Potassium Uptake, Sweet Corn

\section{Introduction}

Sweet corn is one of the most valuable crops in Indonesia with a high demand in the market. Although demand for sweet corn is high, but the productivity number is still low and decreasing. Sweet corn productivity in 2016 was 52.82 quintals ha ${ }^{-1}$ [1]. Meanwhile, it was 51.78 quintal ha $^{-1}$ in 2017 [2]. According to the Data Center and Information System's Ministry of Agriculture, the average growth of sweet corn productivity in 2012-2016 decreased by $3.01 \%$ over the past 5 years [1].

Sweet corn is generally cultivated on dryland. Based on the data of the Indonesian Central Bureau of Statistics in 2016 , total dryland farming in Indonesia was $16,620,113.10$ hectares and distributed about 775,195.00 hectares in West Java [3]. Dryland consists of various types of soil; one of them is Inceptisols. Inceptisols is a young soil resulted from the weathering of parent material in the tropical zone so the wet and dry season influence moderate weathering and leaching [4]. If Inceptisols has not developed further, it is quite fertile to increase the harvested area of sweet corn potentially.

The potential of Inceptisols cannot fully guarantee the productivity of sweet corn. The problem is the fine physical characteristics of Inceptisols are not followed by its chemical characteristics, namely the soil $\mathrm{pH}$ is acidic to slightly acidic and nutrient deficiency of $\mathrm{N}, \mathrm{P}, \mathrm{K}, \mathrm{Ca}$ and $\mathrm{Mg}$ due to intensive leaching level [5]. Fertilization with the appropriate dosage and composition is able to provide the availability of the essential nutrients for plants.

Inorganic fertilizer commonly used by the farmers is NPK fertilizer in the form of singular or compound. Singular NPK only consists of N, P, and K nutrients. Meanwhile, compound NPK does not only consist of 
primary macronutrients but also the other secondary macronutrients. Secondary macronutrients like $\mathrm{Mg}$ is much needed by plants in creating chlorophyll to affect the photosynthesis process and yield of plant biomass along with the potassium nutrient. Magnesium nutrient also plays a role in maintaining soil $\mathrm{pH}$ at 6.5-7.5 [6]. The combination of $750 \mathrm{~kg} \mathrm{ha}^{-1} \mathrm{NPK}$ fertilizer with $\mathrm{Mg}$ had shown a significant effect on yield of sweet corn in the dry weight of seeds per plant and the weight of 100 [7].

Effects of inorganic fertilizers application in improving potassium uptake and crop yields have been demonstrated. Recently, the application of NPK fertilizer 15:15:15 to Talenta sweet corn at a dose of $100 \mathrm{~kg} \mathrm{ha}^{-1}$ was reported to be able to increase the production of cobs per plot by $4.30 \mathrm{~kg}$ [8] The application of NPK fertilizer 15:15:15 on Inceptisols significantly affected the highest potassium uptake in sweet corn at a dose of $400 \mathrm{~kg} \mathrm{ha}^{-1}$ [9]. The objective of this research was to investigate the effect of $\mathrm{NPK}+\mathrm{Mg}$ fertilizer application that contained $12 \% \mathrm{~N}, 12 \% \mathrm{P}_{2} \mathrm{O}_{5}, 17 \% \mathrm{~K}_{2} \mathrm{O}$, and $9 \%$ additional $\mathrm{MgO}$ on potassium availability, potassium uptake, and yield of sweet corn grown on Inceptisols from Jatinangor, West Java.

\section{Materials and Methods}

\subsection{Site Description}

A field experiment was conducted in May to August 2019 at the experimental field station of Agriculture Faculty, Universitas Padjadjaran (6 ${ }^{\circ} 54^{\prime} 56.4^{\prime \prime} \mathrm{S}$ and 107 $\left.{ }^{\circ} 46^{\prime} 16.9^{\prime \prime} \mathrm{E}\right)$. The elevation of the area is approximately $625 \mathrm{~m}$ above sea level. The results of a previous study showed that the Inceptisols characteristics in the experimental station include $\mathrm{pH}$ of 5.52, C-Organic of $3.09 \%$, total $\mathrm{N}$ content of $0.25 \%$, $\mathrm{C} / \mathrm{N}$ ratio of 12 , total $\mathrm{P}$ content of $36.51 \mathrm{mg} 100 \mathrm{~g}^{-1}$, total $\mathrm{K}$ content of $26.21 \mathrm{mg} 100 \mathrm{~g}^{-1}$, soil texture of clay, CEC of $26.68 \mathrm{cmol} \mathrm{kg}^{-1}$, and base saturation of $29.91 \%$.

\subsection{Experimental Design}

The study arranged in a Randomized Block Design consisted of 6 treatments and 4 replicates. In total, there were 24 plots. The size of each plot was $6 \mathrm{~m}^{2}(2 \times 3 \mathrm{~m})$. The treatments were as followed: $\mathrm{A}=\mathrm{C}$ Control, $\mathrm{B}=\mathrm{S}$ tandard NPK, $\mathrm{C}=1 / 2 \mathrm{NPK}+\mathrm{Mg}, \mathrm{D}=1 \mathrm{NPK}+\mathrm{Mg}, \mathrm{E}=1 \quad 1 / 2 \mathrm{NPK}+\mathrm{Mg}$, and $\mathrm{F}=2$ $\mathrm{NPK}+\mathrm{Mg}$. The recommended doses of inorganic fertilizers used in this study were $300 \mathrm{~kg} \mathrm{ha}^{-1}$ urea, $150 \mathrm{~kg} \mathrm{ha}^{-1} \mathrm{SP}-36$ and $50 \mathrm{~kg} \mathrm{ha}^{-1} \mathrm{KCl}$. The organic fertilizer used as a basic manure fertilizer with a dose 5000 ton $\mathrm{ha}^{-1}$.

\subsection{Plant Sampling and Analysis}

Available potassium concentration in soil and potassium uptake by sweet corn were measured on five randomly selected plant and soil samples from each plot at 56 days after planting. The soil samples were taken on the rhizosphere area, and they were air-dried for a week before analyzed. Meanwhile, for sweet corn leaves were sampled at tasseling stage (maximum growth). Leaf samples were oven- dried at $65^{\circ} \mathrm{C}$ for 120 hours to reach a constant weight, and ground for further analyses. Available potassium concentration in soil analyzed by the Atomic Absorption Spectrophotometry (AAS) method with $\mathrm{NH}_{4} \mathrm{OAc} 1 \mathrm{~N} \mathrm{pH} 7$. Potassium content in the plant materials was determined using the wet assays method with $\mathrm{HNO}_{3}$ and $\mathrm{HClO}_{4}$. The sweet corns were harvested at 70 days after planting and were calculated based on the weight of husk-corn cob for every plot.

\subsection{Data Analysis}

Data analysis using One-way Analysis of Variance (ANOVA) and Duncan's Multiple Range Test (DMRT) performed to determine the differences among the fertilizer treatments. A difference at 5\% significance level was used. All statistical analyses were performed using the SPSS software package (version 25).

\section{Results and Discussion}

\subsection{Potassium Availability}

The application of $\mathrm{NPK}+\mathrm{Mg}$ affects potassium availability in Inceptisols. The effects of each treatment are presented in Table 1. The results show that the application of $1 \mathrm{NPK}+\mathrm{Mg}$ fertilizer can increase the availability of potassium in soil from $1,74 \mathrm{cmol} \mathrm{kg}^{-1}$ (control treatment) to $2,25 \mathrm{cmol} \mathrm{kg}^{-1}$.

Table 1. Application NPK $+M g$ on Potassium Availability in Soil.

\begin{tabular}{lll}
\hline Code & Treatments & $\begin{array}{l}\text { Potassium Availability } \\
\left(\mathbf{c m o l ~ k g}^{-1}\right)\end{array}$ \\
\hline A & Control (Without Inorganic & $1,74 \mathrm{a}$ \\
$\mathrm{B}$ & Fertilizer Treatment) & $2,37 \mathrm{~b}$ \\
$\mathrm{C}$ & Standard N, P, K & $1,70 \mathrm{a}$ \\
$\mathrm{D}$ & $1 / 2$ Dose of NPK $+\mathrm{Mg}$ & $2,25 \mathrm{~b}$ \\
$\mathrm{E}$ & 1 Dose of NPK $+\mathrm{Mg}$ & $1,63 \mathrm{a}$ \\
$\mathrm{F}$ & $11 / 2$ Dose of NPK $+\mathrm{Mg}$ & $1,70 \mathrm{a}$ \\
\hline
\end{tabular}

Note: The numbers followed by the same letters in each column are not significantly different according to the Duncan's Multiple Range Test at 5\% level.

The further results of potassium availability show that the treatment of 1 dose of $\mathrm{NPK}+\mathrm{Mg}$ is not significantly different from the standard $\mathrm{N}, \mathrm{P}, \mathrm{K}$ fertilizer treatment. 1 dose of $\mathrm{NPK}+\mathrm{Mg}$ usage is considered to substitute the standard $\mathrm{N}, \mathrm{P}$, $\mathrm{K}$ fertilizer for supplying nutrient availability, especially potassium in Inceptisols Jatinangor. Compound fertilizer is considered more effective than singular fertilizer because it is more practical when applied, is more efficient in terms of labor and time use, is complete in their nutrient content, and is easier to distribute and store [10].

Generally, each dose enhancement of $\mathrm{NPK}+\mathrm{Mg}$ fertilizer causes of available $\mathrm{N}, \mathrm{P}, \mathrm{K}, \mathrm{Mg}$ concentration are higher and increasing the growth of sweet corn [10]. However, in E and $\mathrm{F}$ treatments, the fertilization of $\mathrm{NPK}+\mathrm{Mg}$ showed a decrease in the availability of potassium. Potassium loss is very likely to occur because it is highly mobile in the soil. In reference 
[11], potassium available in the soil does not always remain available, but it is still possible to change into other forms which are slow to be absorbed by plants (not available).

The potassium available in the soil consists of potassium dissolved in the soil solution and potassium in interchangeable soil colloids. Potassium exchange in this colloidal soil can happen naturally because of organic acid exudates from plant roots or the production of $\mathrm{H}^{+}$ions from weathering organic material. Furthermore, $\mathrm{H}^{+}$ions are able to replace $\mathrm{K}^{+}$ions from sorption complexes so that potassium becomes available and can be absorbed by plants. Besides, potassium exchange can be stimulated by a decrease in the concentration of $\mathrm{K}^{+}$ions in soil solution due to leaching or absorption process of $\mathrm{K}$ by plants [12].

\subsection{Potassium Uptake}

The results of variance analysis about $\mathrm{NPK}+\mathrm{Mg}$ application in each treatment are presented in Table 2. The highest potassium uptake of $1,56 \%$ is measured in the plot applied with 1 dose of $\mathrm{NPK}+\mathrm{Mg}$ fertilizer (D treatment). Statistically, potassium uptake by sweet corn plants is not significantly affected by fertilization. B, C, E, and F treatments are not significantly different from $\mathrm{D}$ treatment or control.

Table 2. Application NPK+Mg fertilizer on Potassium Uptake.

\begin{tabular}{lll}
\hline Code & Treatments & Potassium Uptake (\%) \\
\hline A & Control (Without Inorganic & $1,27 \mathrm{a}$ \\
& Fertilizer Treatment) & \\
B & Standard N, P, K & $1,42 \mathrm{ab}$ \\
C & $1 / 2$ Dose of NPK $+\mathrm{Mg}$ & $1,48 \mathrm{ab}$ \\
$\mathrm{D}$ & 1 Dose of NPK $+\mathrm{Mg}$ & $1,56 \mathrm{~b}$ \\
$\mathrm{E}$ & 1112 Dose of NPK $+\mathrm{Mg}$ & $1,50 \mathrm{ab}$ \\
$\mathrm{F}$ & 2 Dose of NPK $+\mathrm{Mg}$ & $1,40 \mathrm{ab}$ \\
\hline
\end{tabular}

Note: The numbers followed by the same letters in each column are not significantly different according to the Duncan's Multiple Range Test at 5\% level.

Table 2 shows that plants give a response to the addition of $\mathrm{NPK}+\mathrm{Mg}$ fertilizer, which is seen in the increase of plant potassium absorption. Although in general, 1 dose of $\mathrm{NPK}+\mathrm{Mg}$ fertilizer application is the highest potassium uptake by the plant, it does not show any significant difference to the $\mathrm{B}, \mathrm{C}, \mathrm{E}$, and $\mathrm{F}$ treatments. Therefore, the use of $1 / 2$ dose of $\mathrm{NPK}+\mathrm{Mg}$ fertilizer is considered as the most efficient dose in increasing the absorption of potassium by sweet corn. The potassium concentration plays a role in maintaining nutrient balance in the soil both on nitrogen and on phosphorus concentration. Potassium is also needed to the osmotic and turgor pressure in plants so that photosynthesis, transpiration rate, and stomata control increase as potassium uptake by sweet corn increases [13].

\subsection{The Yield of Sweet Corn}

The component of yield measured in this study is the weight of husk-corn cob. The result shows that there are significant differences in the effects of the $\mathrm{D}, \mathrm{E}$, and $\mathrm{F}$ treatments in the yield components of sweet corn (Table 3). It proves that $\mathrm{NPK}+\mathrm{Mg}$ fertilizer application can increase the sweet corn production compared to the control treatment.

The E treatment has the highest yield compared to other treatments. This result shows no significant difference compared to $\mathrm{F}$ and $\mathrm{D}$ treatments so that the efficiency of fertilizing 1 dose of $\mathrm{NPK}+\mathrm{Mg}$ can increase the yield of sweet corn at the field. However, the results of this study are still below the Ministry of Agriculture's production target range in the description of Talenta varieties. This is presumably due to the high intensity of sunlight in the dry season so that soil moisture becomes low. Too high of light intensity reduces the plant productivity both in quantity and quality [14].

Table 3. Application NPK+Mg Fertilizer on the Yield of Sweet Corn.

\begin{tabular}{|c|c|c|c|}
\hline \multirow{2}{*}{ Code } & \multirow{2}{*}{ Treatments } & \multicolumn{2}{|l|}{ Crop Yield } \\
\hline & & kg 6 square $\mathrm{m}^{-1}$ & ton $\mathrm{ha}^{-1}$ \\
\hline A & $\begin{array}{l}\text { Control (Without Inorganic } \\
\text { Fertilizer Treatment) }\end{array}$ & $3,43 \mathrm{a}$ & 4,85 \\
\hline B & Standard N, P, K & $4,80 \mathrm{abc}$ & 6,80 \\
\hline $\mathrm{C}$ & $1 / 2$ Dose of $\mathrm{NPK}+\mathrm{Mg}$ & $4,55 \mathrm{ab}$ & 6,45 \\
\hline $\mathrm{D}$ & 1 Dose of $\mathrm{NPK}+\mathrm{Mg}$ & $6,13 \mathrm{~cd}$ & 8,68 \\
\hline $\mathrm{E}$ & $1 \frac{1}{2}$ Dose of $\mathrm{NPK}+\mathrm{Mg}$ & $6,25 \mathrm{~d}$ & 8,85 \\
\hline $\mathrm{F}$ & 2 Dose of $\mathrm{NPK}+\mathrm{Mg}$ & $5,78 \mathrm{bcd}$ & 8,18 \\
\hline
\end{tabular}

Note: The numbers followed by the same letters in each column are not significantly different according to the Duncan's Multiple Range Test at 5\% level.

The production of biomass determines the yield of a plant during the growth period of the plant which is triggered by the availability and absorption of the nutrients, especially $\mathrm{N}$, $\mathrm{P}, \mathrm{K}$ during the fertilization process. Plants will flourish if the nutrients needed are sufficiently available and easily absorbed by plants [6]. The addition of $\mathrm{Mg}$ nutrients to $\mathrm{NPK}+\mathrm{Mg}$ fertilizer is also assumed to give an effect to increase the crop yields, it can be seen in E treatment is significantly different with B treatment. The presence of magnesium plays a role in the formation of chlorophyll and enzyme activators so that it can increase the rate of photosynthetic reactions that will affect to the higher photosynthate. The photosynthates that have been produced are beneficial for plant growth, seed filling and fruit formation to gain more weight of the cob [15].

\section{Conclusions}

The study showed that the productivity of sweet corn plants is considerably higher when using the application of $\mathrm{NPK}+\mathrm{Mg}$ fertilizer. The study has shown that the potassium availability, potassium uptake, and yields of sweet corn from plot applied without inorganic fertilizer (control) is significantly lower than those from inorganic fertilizer plots. Also, the yields of sweet corn plants from plots applied with $\mathrm{NPK}+\mathrm{Mg}$ are significantly higher than the yields from standard NPK application. Farmers can use NPK+Mg compound fertilizers than singular NPK to cultivate sweet corn. 


\section{Acknowledgements}

The research funding was provided by Soil Chemistry and Plant Nutrition Laboratory, Faculty of Agriculture, Universitas Padjadjaran in 2019.

\section{References}

[1] Chafid M, L Nuryati, B Waryanto, Akbar, R Widaningsih. 2016. Agricultural Outlook of Food Crop: Maize. Data Center and Information System's Ministry of Agriculture, Jakarta.

[2] Indonesian Central Agency of Statistics. 2017. Statistic of Indonesia. Central Bureau of Statistics, Jakarta.

[3] Data Center and Information System of Agriculture. 2017. Agricultural Land Statistics 2011-2016. Ministry of Agriculture, Jakarta.

[4] Ketaren SE, P Marbun, P Marpaung. 2014. Inceptisol Soil Classification on the Various Elevation at Sub District of Lintong Ni Huta, Regency of Humbang Hasundutan. Agroekoteknologi 2: 1451-1458.

[5] Halasan A and R Hasanudin. 2018. Change in Soil Chemical Characteristics and Yield of Maize in Inceptisols as Amended with Compost. Ilmu-Ilmu Pertanian Indonesia 20: 33-39.

[6] Suntoro and P Astuti. 2014. Effect of Application Time and NPK Fertilizer Dosage on The Growth of Sweet Corn, Sweet Boys Variety. AGRIFOR XIII: 213-222.

[7] Surbakti MF, S Ginting, and J Ginting. 2013. The Growth and Production of Corn (Zea mays L.) Pioneer-12 Variety of Pruning Leaves and Giving $\mathrm{NPK}+\mathrm{Mg}$ Fertilizer. Agroekoteknologi 1: 523-534.
[8] Panjaitan IA, Hasibuan, and Safruddin. 2018. Effect of Solid Fertilizer and NPK Fertilizer Application on Growth and Yield of Sweet Corn (Zea mays saccharata Sturt.). BERNAS Agricultural Research Journal 14: 91-100.

[9] Kasno A and T Rostaman. 2013. Nutrient Uptake and Maize Productivity due to NPK Compound Fertilizer Application. Penelitian Pertanian Tanaman Pangan 32: 179-186.

[10] Sitepu, A and Adiwirman. 2017. Growth Response and Sweet Corn Production (Zea mays var. saccharata Sturt) on Solid Waste of Palm Oil Factory and NPK. Mahasiswa Faperta UR 4: $1-18$.

[11] Fi'liyah, Nurjaya, and Syekhfani. 2016. Effects of $\mathrm{KCl}$ Fertilizer on Soil N, P, K and Nutrient Uptake by Maize Plant in Inceptisols Situ Hilir, Cibungbulang, Bogor. Tanah dan Sumberdaya Lahan 3: 329-337.

[12] Nursyamsi D. 2011. Mechanisms of Releasing Fixed Potassium as Available Nutrient for Plant Growth on Smectitic Soils. Sumber Daya Lahan 5: 61-74.

[13] Hussain A, M Arshad, Z Ahmad, HT Ahmad, M Afzal, M Ahmad. 2015. Potassium Fertilization Influences Growth, Physiology and Nutrients Uptake of Maize (Zea mays L.). Cercetări Agronomice în Moldova XLVIII: 37-50.

[14] Akmalia HA and E Suharyanto. 2017. Physiological Resposes and 'Sweet Boy-02' Maize (Zea mays L.) Productivity in Different Light and Water Treatment. Teknosains 2: 59-70.

[15] Noza L, H Yetti, and MA Khoiri. 2014. Dolomite and N, P, K Fertilizers Effect on Growth and Yield of Sweet Corn (Zea mays saccharata Sturt) in Peat Land. Mahasiswa Faperta UR 1: $1-11$. 